The Geneva Papers on Risk and Insurance, 18 (No. 69, October 1993), 344-374

\title{
Insurance System Reform and The Future of the Life Insurance Business in Japan
}

\author{
by Terumichi Tsuchida*
}

\section{The Japanese life insurance market today}

\subsection{Providers of life insurance coverage in Japan}

Life insurance coverage in Japan is provided by private life insurance companies, the Post Office Life Insurance Bureau of the Ministry of Posts and Telecommunications, and various types of cooperative associations. At present, 30 private life insurers are authorized to do life insurance business in Japan, where 27 life insurers are domestic companies and the remaining three insurers are branch operations of foreign insurers. Among 27 domestic life insurers, foreign insurers have a stake in five companies, including two wholly-owned subsidiary companies. Sixteen life insurers out of 27 are mutual companies, while the remaining 11 life insurers are joint-stock companies, most of which were established rather recently.

The Meiji Life Insurance Company, Limited, established in 1881 as a joint-stock company, was Japan's first modern life insurance company. ${ }^{1}$ Afterwards, while a large number of insurers were established in the $1880 \mathrm{~s}$, most of them became insolvent and failed due to poor management. Under such circumstances, and as the needs to supervise the insurance business more strictly were strongly voiced, provisions regarding the regulation of the insurance business became effective in 1898 as a part of the old version of the Commercial Code, and the licensing system of insurers was introduced. The old version of the Insurance Business Law was enacted in 1900 , which for the first time included a provision regarding mutual insurers. In 1902 The Dai-ichi Mutual Life Insurance Company was founded as the first mutual insurer in Japan.

While all life insurers in Japan except for three companies were joint-stock companies at the end of World War II, by 1948 there existed 16 mutual companies and four joint-stock companies, as most of life insurers in Japan decided to mutualize in reorganizing their operations. During the following 30 years, up to the 1970s, when foreign life insurers were authorized to do business in Japan, only 20 life insurers operated in Japan, with no new

\footnotetext{
" Chairman of the Board, The Meiji Mutual Life Insurance Company, Tokyo.

${ }^{1}$ The company was mutualized in 1947 and changed its name to The Meiji Mutual Life Insurance Company.
} 
entrants. Although severely impaired by the Financial Crisis in 1927 and World War II, private life insurers in Japan have attained a steady and remarkable growth. As Table 1 shows, at the end of fiscal 1991, which ended March 1992, private life insurers in Japan had over $¥ 1,700$ trillion (US $\$ 14,453$ billion) of life insurance in force and about $¥ 143$ trillion (US $\$ 1,194$ billion) of total assets. The life insurance industry in Japan has become one of the largest life insurance markets in the world. ${ }^{2}$

Table 1: Growth of life insurance in force in Japan

(Trillions of Yen)

\begin{tabular}{|c|c|c|c|c|}
\hline $\begin{array}{c}\text { Fiscal Year } \\
\text { End }\end{array}$ & $\begin{array}{c}\text { Individual } \\
\text { Life }\end{array}$ & Group Life & Total & Mutual Cos. \\
\hline 1955 & 1.9 & 0.3 & 2.2 & 2.1 \\
\hline 1965 & 21.1 & 3.3 & 24.4 & 23.3 \\
\hline 1975 & 173.0 & 92.4 & 265.4 & 248.5 \\
\hline 1985 & 601.2 & 270.1 & 871.3 & 812.8 \\
\hline 1991 & $1,215.0$ & 519.3 & $1,734.3$ & $1,621.1$ \\
\hline $\begin{array}{c}\text { US Dollars } \\
\text { I }\end{array}$ & $10,124.9$ & $4,327.6$ & $14,452.5$ & $13,509.2$ \\
\hline
\end{tabular}

Note: Figures represent the total business of private life insurance companies only. For reference, figures for 1991 are also indicated in billions of US Dollars.

Source: The Life Insurance Association of Japan.

Post Office Life Insurance was established in 1916 as a national monopolistic life insurance program and was originally designed to offer small-sized life insurance policies with no medical examination. In those days, private life insurers marketed mainly life insurance policies with annual or semi-annual premiums and requiring a medical examination to medium and high income family markets. Therefore, Post Office Life Insurance, offering life insurance policies with monthly premiums and requiring no medical examination, was established as a part of the social policy aiming to improve living conditions of low-income families. Although Post Office Life Insurance lost its primary role and function when its monopolistic status was abolished in 1946 and private life insurers introduced small-sized life insurance policies with no medical examination and monthly premiums, it continued to expand its operations by diversifying its product lines and raising the issue limit of life insurance policies. As of March 1992, Post Office Life Insurance is the world largest life insurer with $¥ 147$ trillion (US $\$ 1,227$ billion) of life insurance in force and $¥ 58$ trillion (US $\$ 482$ billion) of total assets. The competition between private life insurers and Post Office Life Insurance has become very intense and thus a controversial issue.

${ }^{2}$ Figures in US Dollars are shown for reference in this paper, using the rate of $¥ 120$ to US $\$ 1.00$. 
Fraternal insurance coverage in Japan is provided by various types of cooperative associations which were established pursuant to various laws. Fraternal insurance programs provided and administered by The Agricultural Cooperative Association and The Zenrosai National Federation of Workers and Consumers Insurance Cooperatives are the two most famous fraternal insurance programs. The Agricultural Cooperative Association has been conducting its fraternal life insurance business since 1952, pursuant to the Agricultural Cooperative Association Law and subject to the supervision of the Ministry of Agriculture, Forestry and Fisheries. At that time, only members of the Association and their families were eligible to purchase life insurance coverage provided by the Association. However, as the range of eligible customers was broadened, the competition between the Association and private life insurers intensified. Moreover, the Association has been providing a wide range of products and services, including property/casualty insurance policies and savings plans, since its inception. As of the end of March 1992, the fraternal life insurance in force of the Agricultural Cooperative Association amounted to $¥ 212$ trillion (US $\$ 1,759$ billion).

\subsection{Life insurance ownership in Japan}

At the end of fiscal 1991, private life insurers in Japan had approximately 524 million policies and $¥ 1,734$ trillion (US $\$ 14,453$ billion) of life insurance in force. The per capita amount of death benefit is approximately $¥ 15$ million (US $\$ 121,000$ ). Individual life insurance in force totalled $¥ 1,215$ trillion, representing $70.1 \%$ of all life insurance in force in Japan, while group life insurance, which provided $¥ 519$ trillion of protection, accounted for $29.9 \%$ of total in-force. As Table 2 indicates, where figures regarding life insurance in

Table 2: Life insurance in force in major countries (as of December 1990)

\begin{tabular}{|l|l|r|r|r|r|}
\hline Country & Currency & $\begin{array}{c}\text { Life } \\
\text { insurance } \\
\text { in force } \\
\text { (billion) }\end{array}$ & $\begin{array}{c}\text { Ratio of life } \\
\text { ins. in force } \\
\text { to national } \\
\text { income }(\%)\end{array}$ & $\begin{array}{c}\text { Life insurance } \\
\text { in force } \\
\text { per capita } \\
\text { (¥ thousand) }\end{array}$ & $\begin{array}{r}\text { Premium } \\
\text { receipts } \\
\text { (million) }\end{array}$ \\
\hline Japan & Yen & $1,565,189$ & 475.5 & 12,984 & $27,320,700$ \\
United States & Dollar & 9,393 & 215.0 & 5,051 & 205,756 \\
France & Franc & 10,000 & 219.8 & 4,619 & 200,447 \\
Germany (F.R.) & D. Mark & 1,750 & 101.2 & 2,490 & 53,164 \\
United Kingdom & Pound & 582 & 151.9 & 2,624 & 34,050 \\
Canada & C. Dollar & 1,157 & 237.7 & 5,041 & 18,572 \\
\hline
\end{tabular}

Note: $\quad$ 1. Figures for Japan represent the total business of private life insurance companies only.

2. Life insurance in force and premium receipts are indicated in each currency. Premium receipts represent the income amount recorded in 1990

Source: 1. Life insurance in force figures in countries other than Japan are from American Council of Life Insurance. Figure for Japan is from The Life Insurance Association of Japan. Life insurance in force in Japan excludes individual annuities.

2. Premium receipt figures are from Swiss Reinsurance Co. and include both life insurance premiums and annuity considerations.

3. Other figures are from Japan Institute of Life Insurance. 
various nations are shown, Japan has grown to become one of the largest life insurance markets in the world in terms of various measures including total life insurance in force, its ratio to national income, per capita amount of death benefit and premium receipt.

According to a national survey conducted in June 1991 by the Japan Institute of Life Insurance, $93.7 \%$ of all households surveyed had some form of life insurance coverage, while $80.5 \%$ of those had some coverage from private life insurers. As this overall life insurance ownership ratio indicates, most of consumers have some form of death protection type product. In addition, according to the survey, consumers responded that, in case of breadwinner’s premature death, at least $¥ 66.6$ million (US $\$ 555,000$ ) would be necessary to support family members. In reality, however, the average size of death benefit per breadwinner amounted to $¥ 24.3$ million (US $\$ 203,000$ ), which is far below the level deemed necessary. While it is quite unlikely that life insurance benefits would be a sole source of funds for a family after the breadwinner's death, it follows that consumers expectations for a role of life insurance are very large and that there still exists a potential need for life insurance purchases in the years ahead.

As Table 3 and Table 4 show, another trend in the Japanese life insurance market in recent years is the rapid growth of group annuity and individual annuity markets, as consumers, in response to the rapid process of population aging, have become more interested in and concerned with income security after retirement.

Table 3: Growth of premium receipts by plan type in Japan

(Billions of Yen, \%)

\begin{tabular}{|c|c|r|r|r|r|}
\hline Fiscal year & $\begin{array}{c}\text { Individual } \\
\text { life }\end{array}$ & $\begin{array}{c}\text { Individual } \\
\text { annuity }\end{array}$ & $\begin{array}{c}\text { Group } \\
\text { life }\end{array}$ & $\begin{array}{c}\text { Group } \\
\text { annuity }\end{array}$ & Total \\
\hline 1965 & $699(94.2)$ & $8(1.1)$ & $28(3.7)$ & $7(0.9)$ & 742 \\
\hline 1975 & $3,345(84.0)$ & $14(0.4)$ & $318(8.0)$ & $300(7.5)$ & 3,981 \\
\hline 1985 & $12,116(78.3)$ & $367(2.4)$ & $929(6.0)$ & $1,900(12.3)$ & 15,480 \\
\hline 1991 & $16,999(60.2)$ & $1,788(6.3)$ & $1,465(5.2)$ & $7,580(26.9)$ & 28,240 \\
\hline $\begin{array}{c}\text { I US Dollars } \\
\text { | }\end{array}$ & 141.7 & 14.9 & 12.2 & 63.2 & 235.3 \\
\hline
\end{tabular}

Note: 1. Figures represent the total business of private life insurance companies only. For reference, figures for 1991 are also indicated in billions of US Dollars.

2. Figures in parenthesis indicate the ratio of each plan type to total.

Source: The Life Insurance Association of Japan. 
Table 4: Growth of policy reserves by plan type in Japan

(Billions of Yen, \%)

\begin{tabular}{|c|c|c|c|c|}
\hline $\begin{array}{c}\text { Fiscal Year } \\
\text { end }\end{array}$ & $\begin{array}{c}\text { Individual } \\
\text { life }\end{array}$ & $\begin{array}{c}\text { Individual } \\
\text { annuity }\end{array}$ & $\begin{array}{c}\text { Group } \\
\text { annuity }\end{array}$ & $\begin{array}{c}\text { Total } \\
\text { assets }\end{array}$ \\
\hline 1965 & $1,767(78.8)$ & $13(0.6)$ & $83(3.7)$ & 2,243 \\
\hline 1975 & $9,526(73.9)$ & $113(0.9)$ & $980(7.6)$ & 12,896 \\
\hline 1985 & $35,057(65.1)$ & $1,204(2.2)$ & $9,476(17.6)$ & 53,871 \\
\hline 1991 & $79,898(55.8)$ & $9,748(6.8)$ & $37,925(26.5)$ & 143,234 \\
\hline USDollars & 665.8 & 81.2 & 316.0 & $1,193.6$ \\
\hline
\end{tabular}

Note: 1. Figures represent the total business of private life insurance companies only. For reference, figures for 1991 are also indicated in billions of US Dollars.

2. Reserve figures for 1965 include premium reserves only, while figures for other years include premium reserves, unearned premiums, and contingency reserves.

3. Figures in parenthesis indicate the ratio of each category of reserves to total assets.

Source: The Life Insurance Association of Japan.

\subsection{Private life insurers in the financial and capital markets in Japan}

At the end of fiscal 1992, total assets held by all private life insurers in Japan amounted to $¥ 143$ trillion (US $\$ 1,194$ billion), accounting for the second highest proportion $(12.8 \%)$ of the aggregate funds held by private financial institutions, with bank accounts of all banks being the highest (Refer to Table 5). During the prewar period, life insurers' assets once accounted for more than $12 \%$ of aggregate fund held by private financial institutions. As their operations were severely impaired by the war, their share was less than $3 \%$ throughout the $1950 \mathrm{~s}$. Afterwards, private life insurers regained their position as a major financial institution and thus they are playing an important role in the Japanese economy and society.

At fiscal year-end 1991, a major portion of the industry's assets was invested in securities and commercial loans. Securities holdings reached $¥ 63$ trillion (US $\$ 524$ billion) and the balance of commercial loans amounted to $¥ 56$ trillion (US $\$ 469$ billion). These two categories of investment accounted for $83.2 \%$ of total assets. As for the breakdown of securities holdings, domestic stocks stood at $¥ 31$ trillion (US $\$ 257$ billion), representing the highest proportion, while domestic bonds amounted to $¥ 13$ trillion (US $\$ 109$ billion) and foreign securities reached $¥ 19$ trillion (US $\$ 157$ billion). According to Table 6 , which lists major stockholders of listed companies by type, life insurers are among the largest stockholders along with city banks, long-term credit banks and regional banks. 
Table 5: Sources of funds in Japan by type of private financial institutions

(Billions of Yen, \%)

\begin{tabular}{|l|c|r|r|r|r|r|r|r|}
\hline \multirow{2}{*}{$\begin{array}{l}\text { Financial } \\
\text { Institutions }\end{array}$} & \multicolumn{2}{|c|}{1935} & \multicolumn{2}{c|}{1950} & \multicolumn{2}{c|}{1965} & \multicolumn{2}{|c|}{1975} \\
\cline { 2 - 10 } & Amount & Share & Amount & Share & Amount & Sharc & Amount & Share \\
\hline $\begin{array}{l}\text { All Banks } \\
\text { (Banking Accounts) }\end{array}$ & 13.4 & 67.6 & 1,099 & 74.9 & 26,180 & 66.3 & 124,303 & 55.2 \\
\hline $\begin{array}{l}\text { All Banks } \\
\text { (Trust Accounts) }\end{array}$ & 1.7 & 8.7 & 18 & 1.2 & 3,536 & 9.0 & 20,294 & 9.0 \\
\hline $\begin{array}{l}\text { Credit Associations } \\
\text { (Shinkin Banks }\end{array}$ & 0.2 & 1.1 & 44 & 3.0 & 3,114 & 7.9 & 19,701 & 8.7 \\
\hline $\begin{array}{l}\text { Agricultural } \\
\text { Cooperatives }\end{array}$ & 1.4 & 6.9 & 207 & 14.1 & 2,433 & 6.2 & 15,232 & 6.8 \\
\hline $\begin{array}{l}\text { Life Insurance } \\
\text { Companies }\end{array}$ & 2.5 & 12.6 & 32 & 2.2 & 2,094 & 5.3 & 12,794 & 5.7 \\
\hline $\begin{array}{l}\text { Non-Life Insurance } \\
\text { Companies }\end{array}$ & 0.5 & 2.5 & 24 & 1.6 & 398 & 1.0 & 3,276 & 1.5 \\
\hline Total & 19.9 & 100.0 & 1,467 & 100.0 & 39,483 & 100.0 & 225,278 & 100.0 \\
\hline
\end{tabular}

\begin{tabular}{|l|c|c|cr|r|}
\hline \multirow{2}{*}{$\begin{array}{l}\text { Financial } \\
\text { Institutions }\end{array}$} & \multicolumn{2}{|c|}{1985} & \multicolumn{2}{c|}{1991} \\
\cline { 2 - 6 } & Amount & Share & \multicolumn{2}{|c|}{ Amount } & Share \\
\hline $\begin{array}{l}\text { All Banks } \\
\text { (Banking Accounts) }\end{array}$ & 319,144 & 50.8 & $506,800(4,223.3)$ & 46.7 \\
\hline $\begin{array}{l}\text { All Banks } \\
\text { (Trust Accounts) }\end{array}$ & 54,265 & 8.6 & $106,488 \quad(887.4)$ & 9.8 \\
\hline $\begin{array}{l}\text { Credit Associations } \\
\text { (Shinkin Banks) }\end{array}$ & 50,482 & 8.0 & $85,162 \quad(709.7)$ & 7.9 \\
\hline $\begin{array}{l}\text { Agricultural } \\
\text { Cooperatives }\end{array}$ & 38,736 & 6.2 & $60,625 \quad(505.2)$ & 5.6 \\
\hline $\begin{array}{l}\text { Life Insurance } \\
\text { Companies }\end{array}$ & 52,945 & 8.4 & $138,903(1,157.5)$ & 12.8 \\
\hline $\begin{array}{l}\text { Non-Life Insurance } \\
\text { Companies }\end{array}$ & 10,628 & 1.7 & $24,225 \quad(201.9)$ & 2.2 \\
\hline Total & 627.748 & 100.0 & $1,084,351(9,036.3)$ & 100.0 \\
\hline
\end{tabular}

Note: 1. Figures represent funds held by private financial institutions only.

2. Figures in parenthesis for 1991 are indicated in billions of US Dollars for reference.

3. For 1935, 1950 and 1965, figures represent amounts of funds at the end of each calendar year. For 1975, 1985 and 1991, figures represent amounts of funds at the end of each fiscal year.

Source: Figures for 1935, 1950 and 1965 are from Bank of Japan.

Figures for 1975, 1985 and 1991 are from Japan Institute of Life Insurance. 
Table 6: Stockholdings by type of owners in Japan

\begin{tabular}{|l|c|}
\hline Type of owners & Share $(\%)$ \\
\hline Government and local public bodies & 0.6 \\
\hline Financial institutions & 44.7 \\
\hline Long-term credit, city \& regional banks & 16.3 \\
\hline Trust banks & 9.7 \\
\hline Life insurance companies & 13.2 \\
\hline Non-life insurance companies & 4.0 \\
\hline Business corporations & 24.5 \\
\hline Securities companies & 1.5 \\
\hline Individuals & 23.2 \\
\hline Foreigners & 5.4 \\
\hline
\end{tabular}

Note: Figures indicate ratio of number of shares held by each type of owner to total number of listed shares of 2,106 listed companies as of end of March, 1992.

Source: Tokyo Stock Exchange.

\section{Reform of the financial system and the Insurance Council Report of 1992}

2.1. Discussions regarding reform of the financial system and insurance system in Japan The fundamental framework and structure of the existing financial system in Japan was established after the World War II and it has the following three major characteristics:

(1) Separation of long-term and short-term bank financing businesses. This policy was adopted after the war to promote long-term bank financing activities in an efficient and smooth manner in an era of shortage of capital accumulation. Based on this policy, long-term credit banks and trust banks have been specializing in the mid or long-term bank financing business by raising funds through the issue of savings bonds or the selling of loan trust products, while ordinary banks and mutual banks have been mainly providing short-term bank financing by raising short-term funds through taking deposits.

(2) Separation of banking and trust businesses. This policy was adopted to foster and develop the trust business as a specialized business area by authorizing only trust banks to conduct trust business and prohibiting other financial institutions from engaging in trust business. However, trust banks are not specialized trust companies but ordinary banks which were established pursuant to The Banking Law and authorized to do trust business pursuant to The Law Concerning Concurrent Operation of Trust Business by Ordinary Banks. 
(3) Separation of banking and securities businesses. Pursuant to The Securities and Exchange Law, ordinary banks, trust banks and other types of financial institutions including insurance companies are prohibited from conducting securities business, except for a few security-related activities.

In addition, it is impossible for financial institutions in Japan to circumvent these limitations on scope of activity by establishing a holding company, as the holding company system is prohibited as a part of the antimonopoly policies introduced after the war. As far as the life insurance industry is concerned, insurance companies have been subject to similar limitations on their activities pursuant to the provisions in the Insurance Business Law prohibiting both the non-insurance activity and the composite operation of life and non-life businesses. Thus, the Japanese financial system in the postwar period is characterized by its separation and compartmentalization based on specialities. However, as a result of the issuance of a huge amount of government bonds, which started in the mid 1970 s, and the internationalization of finance, such activity limitations had been gradually eased and an era of deregulation started. As the barriers and distinctions separating each financial sector continued to become lower and blurred, discussions regarding the role and function of financial institutions were initiated and the mood for the reform of the present financial system was heightened. In parallel with the reform of financial system, discussions regarding the reform of insurance system also started.

Several major changes in the market and operating environments can be pointed out as underlying factor which prompted such discussions. First, there emerged a growing tendency among consumers to choose a more attractive product from various types of financial and insurance products based on their own judgment due to the increasing awareness of and preference for higher interest rates. Also, as for the investment operations of life insurers, as the proportion of marketable assets such as stocks and bonds to total assets has been increasing and the deregulation of interest rates controls has advanced, life insurers are now more exposed to investment-related risks, including the risk associated with the fluctuation of market price of assets and the currency exchange risk. Moreover, they are exposed to an increasing level of the insurance underwriting risk and the business risk associated with misjudgment on the part of the management.

Triggered by a steep appreciation of the yen which started in around 1985, an easy money policy was adopted to transform the structure of the Japanese economy into one led by domestic demand. As a result, prices of assets, including stocks and real estate, surged to an unprecedented level and the so-called "Bubble Economy" developed in Japan. Afterwards, the values of assets declined sharply as a result of the introduction of a tight credit policy and insurance companies in Japan have been severely affected by the emergence of the Bubble Economy and its aftermath. Pursuant to the statutory accounting rules, the value of listed securities held by Japanese insurers is evaluated by the lower of cost or market value method. Therefore, an unrealized capital loss on a security is recognized on the balance sheet when its market value is lower than its book value as of a fiscal-year end, while unrealized capital gains are not recognized when the market value is higher than the book value, resulting in the accumulation of unrealized capital gains on securities as an off-balance-sheet item. While soaring values of assets and properties have inflated such unrealized capital gains especially in the case of stocks, these unrealized gains have rapidly decreased due to the lingering slump in the equity markets in recent years. 
In spite of such sweeping changes in the environment surrounding Japanese insurance companies, the Insurance Business Law revised in 1939 and other insurance-related statutes, which had been introduced based on the then prevailing economic and social environments, have not undergone a thorough and comprehensive review for almost half a century. Thus, there have been growing concern with and demands for a reform of the insurance system which would be consistent, and in harmony with, the direction of the financial system reform.

\subsection{History of regulation and supervision pertaining to the insurance business and the} Insurance Council Reports in Japan

(a) History of insurance-related statutes and regulation and the role of the Insurance Council in Japan.

Today, the insurance business in Japan is subject to strict and extensive government controls and is regulated by the Insurance Business Law and other statutes, based on the substantial supervision principle. In the area of regulation of insurance business and companies, there exist three fundamental statutes:

(1) The Insurance Business Law which was enacted in 1900 and revised in 1939. This law, as a fundamental and primary statute for the insurance regulation, provides regulations regarding overall areas of insurance company operations and management, for the purposes of policyholder protection and the sound development of the insurance business. While the Insurance Business Law consists of such major provisions as those regarding the licensing of insurers, the approval of basic documents of insurers and the supervision of day-to-day operations of insurers, its jurisdiction is more extensive and broader than its counterparts in foreign countries.

(2) The Law Concerning the Control of Insurance Solicitation which became effective in 1948. This law provides for the regulations regarding insurance solicitation for the purposes of ensuring the eligibility of insurance solicitors and preventing unfair trade practices.

(3) The Law Concerning Foreign Insurers which became effective in 1949. This law was introduced to regulate foreign insurers operating in Japan in the same manner as domestic insurers. Thus, this law includes a similar set of provisions as included in the two statutes above-mentioned.

Besides those laws, there exist the Ordinance Concerning the Enforcement of the Insurance Business Law and the Enforcement Regulation of Insurance Business Law, which serve as supplement to the Insurance Business Law. In addition, there are the Law Concerning Non-Life Insurance Rating Organizations and other statutes concerning specific areas of insurance business. While they are not statutes, the Banking Bureau of the Ministry of Finance issues various regulatory notices as administrative guidance to regulate insurance companies on a more strict basis.

Let us review briefly the history of insurance regulation laws in Japan. In the non-life insurance business, The Tokio Marine Insurance Company was founded in 1879 and commenced its insurance business in the field of marine insurance as the first non-life insurer in Japan, while, in the life insurance side, The Meiji Life Insurance Company, Limited was founded in 1881 and commenced its insurance business as the first life insurer in Japan. In those days, however, there existed no laws for the regulation of private insurance business. The first provision pertaining to insurance regulation in Japan dates back to the old 
version of the Commercial Code enacted in 1890, which contained chapters regarding insurance laws serving as both the insurance contract law and the insurance regulation law. While a part of the old Commercial Code became effective in 1893, the enforcement of insurance-related provisions was postponed until 1898 .

The old Commercial Code was abolished as the new version of the Commercial Code became effective in 1899. At the same time, the provisions pertaining to the supervision of insurance business was temporarily transferred to the Enforcement Act of Commercial Code. The Enforcement Act of Commercial Code contained many important and key provisions which constitute the regulatory framework of the insurance business, including the prohibition of non-insurance activity, the prohibition of the composite operation of life and non-life insurance businesses, the approval of basic documents of insurers, and the Minister's rights to require reports and to conduct examination. In 1900, the old version of the Insurance Business Law became effective and took over the provisions included in the Enforcement Act of Commercial Code. The old Insurance Business Law was modeled on the insurance regulation statutes in Germany which were being compiled at that time and was based on the so-called principle of strict governmental supervision, including the licensing system for the insurance business. It is especially noteworthy that the mutual company was admitted as an entity to do insurance business in addition to the joint-stock company under the old Insurance Business Law. In 1902, The Dai-ichi Mutual Life was established as the first mutual insurance company in Japan. The old Insurance Business Law had been revised and amended partially several times. In 1939, however, it was revised completely and the new version of the Insurance Business Law was enacted, which is still effective today.

The supervisory and administrative authority for insurance companies in Japan was vested in a section in the Ministry of Agriculture and Commerce which was established in 1890. Then, the jurisdiction was transferred to the Ministry of Commerce and Industry which was separated from the Ministry of Agriculture and Commerce in April 1925 and again transferrred to the Ministry of Finance in December 1941. The Ministry of Finance has been in charge since then. Today, the Banking Bureau of the Ministry of Finance has jurisdiction over financial institutions such as banks and insurance companies, while the Securities Bureau has jurisdiction over securities companies. The First Insurance Division of the Insurance Department of the Banking Bureau is in charge of regulation of life insurers, while the Second Insurance Division is in charge of regulation of non-life insurers. Major regulatory and administrative areas and items supervised by the Insurance Department include: (1) the licensing for insurance business, (2) general supervision of insurance companies such as the approval of proposed amendment to basic documents, the approval and guidance of assets investment and accounting, the request to submit and file various forms and reports, the issue of orders which deemed necessary from a regulatory standpoint, and revocation of license, and (3) supervision of insurance solicitation, including the prevention of unfair trade practices.

Moreover, the Insurance Council, composed of selected scholars, consumers and representatives of the insurance industry, was established in 1959 as an advisory body to the Ministry of Finance. Pursuant to an inquiry by the Minister of Finance, the Insurance Council is commissioned to study and discuss important issues with regard to insurance regulation including improvement in the insurance system, and provide recommendations 
and suggestions to the Minister regarding such matters as the Insurance Council deems necessary. The Insurance Council issued its first report entitled "On Life Insurance Accounting" in 1962. About twenty reports had been issued by the Council. These reports have greatly affected the management and operations of life insurance companies.

(b) Outline of the Insurance Council Report of 1992

The Coordinating Committee of the Insurance Council submitted its final report on June 17, 1992, based on over three years of deliberations which started in April 1989, taking into account the deliberations at its two subcommittees on International Affairs and on Insurance Accounting and also referring to the opinions received from various sources. The final report, entitled "The New Course of Insurance Business", reviewed and covered a broad range of issues regarding the insurance business as a whole, with the intention of implementing reform of the insurance system including amendments to statutes. In addition, the Insurance Council Report issued at this time has another distinctive feature in that the Insurance Council tried to make sure that the directions indicated in its report would be consistent with the directions indicated by a report issued in June 1991 by The Financial System Research Council entitled "On a New Japanese Financial System" and a report issued in June 1991 by The Securities and Exchange Council entitled "Fundamental System for the Securities Business". Reviews and discussions by the Insurance Council were conducted from three standpoints: (1) users' standpoint, (2) national economic standpoint, and (3) international context. The following three guidelines and principles were established, namely: (1) promotion of competition and efficiency of the insurance business through deregulation and liberalization, (2) maintenance of soundness of the insurance business, and (3) achievement of fairness and equity in the operations of the insurance business. Major items included in the report are listed below.

(1) Scope of activities for insurance companies

(i) Liberalization of investment methods and operations

(ii) Composite operation of life and non-life business

(iii) Relations between the insurance industry and other sectors of the financial services industry

(2) Distribution of insurance products

(i) Deregulation of distribution and diversification of distribution channels

(ii) Improvement in disclosure of product-related information

(3) Insurance accounting and disclosure

(i) Risk management system

(ii) Policy reserves

(iii) Review of existing formula for distribution of policyholder dividends and treatment of unrealized capital gains

(iv) Introduction and practical use of segment accounting and separate accounts

(v) Improvement in disclosure

(4) Corporate forms of insurance companies

(i) Improvement in management monitoring functions

(ii) Improvement in financial conditions of insurance companies

(iii) Conversion of mutual insurers into stock insurers 
(5) Supervision of insurance business

(i) Deregulation pertaining to insurance products, premium rates, dividend scales and investments

(ii) Measures against financial difficulty or failure of insurers - Introduction of safety-nets such as a guarantee fund.

\section{The Insurance Council Report of $\mathbf{1 9 9 2}$ and its implications}

As we reviewed in the previous chapter, the report issued by the Insurance Council this time covers a very broad range of subjects. It is anticipated that the report will have a significant impact on the future course and development of the life insurance business in Japan at the turn of the century. In this chapter, I will describe several deregulationrelated items which I believe will have considerable implications for the Japanese life insurance business in the future.

\subsection{Deregulation of the prohibition on composite operation of life and non-life businesses}

(a) History of a provision prohibiting the composite operation in Japan

In Japan, an insurer is currently prohibited by the Article 7 of the Insurance Business Law from conducting a composite operation of life and non-life businesses. The first provision with regard to the composite operation in Japan dates back to the old version of the Commercial Code, which became effective in 1893, with the insurance-related provisions in the Code having become effective in 1898. Pursuant to the Article 693 of the old Commercial Code regarding the regulation of insurance operations, an insurer was authorized to conduct a composite operation provided that both the management and the accounting were completely separate and exclusive between life and non-life operations. This article was modeled on the Article 4 of the Life Assurance Companies Act 1870 in the United Kingdom.

Afterwards, a criticism was voiced to the effect that the mere separation of both the management and the accounting is not sufficient and effective and thus the composite operation should be banned. In responding to such criticism, the composite operation was prohibited by Article 97 of the new version of the Commercial Code which became effective in 1899. Article 97 of the new Commercial Code was then transferred to Article 4 of the old version of the Insurance Business Law. When the old Insurance Business Law was partially amended in 1913, Article 4 was amended to include a provision which allowed a life insurer to engage in the life reinsurance business. According to the definitions of life business and non-life business in Japan, which will be briefly discussed later, the reinsurance business belongs to the non-life business. However, as the life reinsurance business shares common actuarial principles with the direct life insurance business, a statutory provision enabling a life insurer to do life reinsurance business was created. When the new Insurance Business Law was enacted in 1939, that provision prohibiting the composite operation was transferred to Article 7, which remains effective today.

As was explained, while an insurer is prohibited from underwriting both life and nonlife risks directly in Japan, it is important to note how the composite operation through a subsidiary or a holding company is regulated and treated in Japan. While the Insurance Business Law has no provisions dealing with the composite operation through a subsidiary or a holding company, the establishment or ownership of a holding company is banned pursuant to the Law Concerning the Prohibition of Private Monopoly and the Maintenance 
of Fair Trade, which was enacted in 1947 for the purpose of preventing the excessive concentration of economic powers. In addition, financial institutions, including banks, insurance companies, and securities firms, are subject to percentage limitations in their stock ownership of other institutions, in order to prevent the excessive concentration of economic powers. In case of an insurer, it is in principle prohibited from owning stock of other corporations in excess of ten percent of total issued and outstanding stock. If an insurer is to own stock of a company in excess of ten percent of total issued and outstanding stock, an insurer is required to obtain approval from the Fair Trade Commission, while the requirements for such approval are not specified in the statutes. As a result, the composite operation through a subsidiary is in reality not possible for the Japanese insurers at present.

(b) The origin of and current developments in the so-called "Third Area" of insurance business

As the Insurance Business Law has no statutory provisions with regard to the definition of the life and non-life business, legal disputes and interpretations thereof had been conducted based on the Commercial Code which includes provisions with regard to the definition of the insurance contract. Pursuant to the Commercial Code, non-life insurance is defined as insurance which pays an indemnity type of benefit against an actual loss arising from a specified contingent event, while life insurance is defined as insurance which pays the fixed type of benefit contingent upon the life or death of an insured person. Based on this definition, it follows that insurance which pays benefit against personal risks other than the life or death of an insured person, such as accident insurance or sickness insurance, does not belong to either life insurance or non-life insurance. While this specific area of insurance business has been commonly called as the "Third Area" in Japan, long and heated discussions have occurred between the life and the non-life industries in relation to the treatment of the "Third Area of Insurance Business".

Given such circumstances, the Ministry of Finance which is in charge of supervising the insurance business issued a guideline in 1965 specifying the roles and functions of both industries in the third area of insurance business. Based on this guideline, several points were temporarily agreed upon, including (1) in the fields of accident and sickness insurance which both industries have already entered, life insurers would not issue an accident insurance policy but would underwrite such risks as a rider, while non-life insurers would not expand the sickness insurance line beyond the existing riders covering sickness-related risks; (2) both industries were urged to develop products based on the features of each industry, whereby life insurers would provide the fixed amount type of benefit and non-life insurers would provide the indemnity type of benefit.

As far as the current developments in this area are concerned, the non-life industry has been expanding the accident and sickness product lines which deal with personal risk exposures since the $1980 \mathrm{~s}$, and also putting an emphasis on nursing care insurance in response to the emerging aging society. Life insurers also have actively developed various products in this area, including sickness, dental and nursing care insurance, and some life insurers have been specializing in this market. Several life insurers also put on the market an insurance product which is quite similar to the disability income policy offered by the non-life insurer. In Japan, while health insurance benefits have been provided as a part of national social security programs based on the Health Insurance Act enacted in 1922, 
there have been growing expectations of private life insurers being able to provide supplemental types of health products due to the escalating medical costs in recent years. As the importance of the third area of insurance business, in which various types of products could be developed, has been increasing for both industries, incessant and continuing discussions and debates regarding product development in this area have occurred even after the regulatory guideline was issued in 1965 .

(c) Recommendations by the Insurance Council Report regarding composite operation and their implications

Reasons why the Insurance Business Law currently prohibits the composite operation include: (1) it is necessary to protect policyholders of life insurance contracts, wherein policy duration is long-term and risks covered are rather uniform and stable in terms of nature and amount, from losses arising from non-life insurance contracts wherein the chance of loss is rather unstable and unpredictable and large risks are more often covered; (2) it is better and more desirable from the standpoints of efficiency and enforceability for the regulatory authorities to regulate an insurer who specializes in either life or non-life business and conducts its operations based on the nature of its specialized business. Moreover, there is a concern from a practical standpoint concerning the effect of competition between life insurers, for which the mutual form is more common and large amount of assets have been accumulated, and non-life insurers, for which the stock form is more common and asset size is relatively smaller.

It has, however, been pointed out that the differences between the life and non-life industry in terms of the nature of risks covered have been narrowing, with the proper transfer and shift of risks underwritten by non-life insurers having been accomplished through the use of reinsurance and with more accurate and detailed statistical information on the probability of losses being available. In addition, the difference between the life insurance contract and the non-life contract in terms of policy duration has been narrowing, as the proportion of both long-term non-life policies with savings feature and shortterm life policies has been increasing. Thus, it is becoming more difficult to identify decisive reasons justifying the prohibition of the composite operation of life and non-life businesses. The fact that the composite operation is being pursued by various cooperative associations providing insurance coverage on a fraternal basis should be also taken into account.

Opinions which recognize the advantages of the composite operation have also been expressed. Such opinions point out that benefits and conveniences to consumers would be enhanced by the introduction of the composite operation in that: (1) it will enable an insurer to develop a packaged product combining a life and a non-life policy and to diversify its insurance services and thus enable the insurance buying public to conduct so-called "One Stop Shopping"; (2) the so-called "Economies of Scope" is accomplished, which will result in improved operational efficiency and the offering of insurance products and services at lower cost; and (3) the competition in the insurance markets will be further promoted by the mutual entry into other areas of insurance business, and reduction of premium rates, a hike of dividend scales and an improved level of insurance services are expected.

As for the situations in European and North American countries, it is in principle prohibited for an insurer to directly conduct a composite operation of life and non-life busi- 
nesses, while in the United Kingdom and Canada certain insurers who had been authorized to conduct the composite operation in the past are allowed to continue to do so as an exception. However, the composite operation through a subsidiary or a holding company is allowed in most countries, while there may exist certain limitations on investments in subsidiaries or holding companies. Thus, in reality, the composite operation has been conducted.

Taking into account findings aforementioned, the Insurance Council recommended the following guidelines with regard to the composite operation of life and non-life insurance businesses.

(1) In principle, an existing provision prohibiting the composite operation of life and nonlife businesses will be reviewed and amended so that the composite operation through a subsidiary can be pursued by an insurer.

(2) As for the method for the composite operation of life and non-life insurance businesses, an approach of incorporating a subsidiary should be pursued. Reasons for such an approach include: (i) proper separation of risks between life and non-life areas can be secured; (ii) the composite operation can be introduced gradually, while taking into account the differences between life and non-life areas in terms of distribution systems and regulation, which arise from different features of each business and its products; and (iii) in most other countries, the composite operation is generally conducted through a subsidiary or a holding company. An insurance subsidiary will be allowed to underwrite all classes of insurance that either a life or non-life insurer is authorized to underwrite.

(3) In introducing the composite operation through a subsidiary, an insurance subsidiary will be permitted to utilize distribution channels of its parent insurer, from perspectives of both consumer benefit and effective usage of existing management resources.

(4) In the third area of insurance business, both life and non-life insurers will be allowed to directly underwrite a broad range of policies, including savings-type policies, for which an insurer can choose either a fixed type or indemnity type of benefit. Considering the fact that some small and medium-sized insurers, including foreign insurers operating in Japan, are specializing in this market, entry into this market by major insurers will be permitted in a gradual manner.

(5) The introduction of composite operation will be accomplished in a gradual and continuous way so that a sudden change in the operating environment can be avoided.

(6) A study for the future amendment to the Insurance Business Law to include provisions for the definition of the life and non-life business should be conducted. Also, certain legislative measures should be taken for the purpose of, among other things, clarifying the classes of insurance which an insurer is authorized to underwrite directly.

In responding to the movement towards the composite operation, some life insurers have put short-term disability income policies on the market, while non-life insurers introduced savings-type accident insurance policies with an annuity payment option. Thus, both life and non-life insurers are becoming more active in directly entering the so-called third area of insurance business. In addition, many insurers in Japan, both life and non-life, established a special organization or division to conduct a feasibility study and do research with regard to the composite operation. 


\subsection{Prornotion of mutual entry into other sectors of financial services - deregulation of prohibition on non-insurance activity}

In addition to the deregulation of the prohibition on the composite operation, the Insurance Council recommended in its report that an existing provision prohibiting noninsurance activity, including the entry into other sectors of financial services, be liberalized. In this section, the proposed easing of the prohibition on non-insurance activity will be reviewed, together with the outline of the financial system reform.

\section{(a) Outline of the current regulation prohibiting non-insurance activity}

At present, an insurer in Japan is in principle prohibited by Article 5 of the Insurance Business Law from engaging in non-insurance activities. This provision was introduced in Japan against a similar background as the one for the provision prohibiting the composite operation. However, there exists a proviso in the Insurance Business Law which enables an insurer to engage in certain non-insurance activities as an exception.

First, as far as the non-insurance activity which a life insurer can pursue directly is concerned, a life insurer is authorized to act as a trustee with regard to paid claims and benefits pursuant to a proviso in Article 5 of the Insurance Business Law. This provision was introduced during the war. In reality, life insurers have not acted as a trustee thus far, due to (1) life insurers being able to provide similar benefits to policyholders or beneficiaries through the settlement options without acting as a trustee, and (2) the trust banks having been opposed to such an action on the part of life insurers.

The entry into non-insurance activity through a subsidiary is in principle prohibited by a provision in an antimonopoly law in Japan, which was previously referred to in relation to the composite operation of life and non-life businesses. The Ministry of Finance has permitted an insurer to engage in certain non-insurance activities through subsidiaries or affiliates for the purposes of enhancing operational efficiency and promoting diversification for an insurer and issued a regulatory notice which stipulated certain requirements to be followed by an insurer in conducting non-insurance activities through subsidiaries. To be more specific, the Ministry issued a regulatory notice in 1965 regarding the relationship between an insurer and its affiliates and other circulars, by which an insurer is authorized to conduct the following non-insurance activities through its subsidiaries or affiliates:

(1) Activities which constitute a part of the insurance business but can be separated from essential and core functions of the insurance business, including computing activity, collateral administration activity, and real estate maintenance and administration activities. Such separate activities are performed by subsidiaries mainly for their parent insurer. Subsidiaries in this category should be incorporated and wholly-owned by the parent insurer, subject to approval of the Fair Trade Commission.

(2) Activities with regard to insurance policies which can be conducted by subsidiaries in lieu of their parent insurer. Activities in this category include claim settlement activity in case of the non-life insurer and solicitation, inspection and premium collection activities in case of the life insurer. While subsidiaries in this category are generally required to be wholly-owned by their parent insurer, the stock ownership ratio of parent insurer and the proportion of revenue from the parent insurer to total revenue can be less than one hundred percent subject to the judgment of the Fair Trade Commission. 
(3) Activities which are incidental or ancillary to the insurance business, including: credit guaranty activity, leasing activity, mortgage acceptance activity, venture capital activity, and investment advisory activity. A parent insurer is prohibited from owning over ten percent of stock of subsidiaries in this category.

(b) Recommendations by the Insurance Council Report regarding the prohibition on noninsurance activity and their implications

While an insurer is currently prohibited from engaging in non-insurance activities by the Insurance Business Law, it is pointed out that the regulation was introduced (1) to secure financial soundness of an insurer, (2) to prevent conflicts of interest among related parties, (3) to enhance regulatory and administrative efficiency, and (4) to promote an effective competitive policy. Since consumers expectations for the savings function of insurance products have been growing in recent years, insurers are strongly expected to conduct their investment operations in a fair and reasonable manner and generate an attractive and competitive level of investment returns which will be properly reflected in the product pricing as the competition with other types of financial institutions, including banks, as well as within the insurance industry are becoming further intensified. In order to carry out the insurance business in an efficient and smooth manner through the realization of optimum investment return under a changing operating environment, an insurer is furthermore required to meet the diversified and sophisticated needs of borrowers for financial services as well as to provide funds as a part of its investment operations.

Moreover, in line with the changes in the economic and financial environments, the reform of both the financial system and the securities business have been studied and contemplated, including the mutual entry into other sectors of financial services. Such reform of both the financial system and the securities business system would enable financial institutions to provide a wider range of financial services to borrowers. In reforming these systems, unless an insurer also is permitted to provide a wider range of financial services, the insurer will encounter deteriorating stability and efficiency in its investment operations, which would result in the inability of an insurer to best serve the interests of policyholders.

As for the situation in North America, the New York Insurance Law, for example, has provisions which authorize both a life insurer and a non-life insurer to engage in any lawful business other than banking and its related businesses through investment in a subsidiary or a holding company. In case of the United Kingdom, France and Germany, an insurer is authorized to engage in any business through investment in a subsidiary or a holding company, while banks are also permitted to enter the insurance business. As a result, the Allfinanz trend and the Bancassurance trend in Germany and in France respectively, are rapidly progressing, whereby various types of alliances, including stock ownership, between insurers and banks have been formed to provide customers with a wide range of bank and insurance products from one source.

Taking into account the findings aforementioned, the Insurance Council recommended the following guidelines with regard to the deregulation of prohibition on non-insurance activities.

(1) With regard to legislative measures, it is appropriate that certain statutory provisions defining and clarifying activities proper to the insurance business and activities inci- 
dental to the insurance business will be created, in reference to various business laws, including the Banking Law.

(2) With regard to insurance-related services, it is appropriate that an insurer will be permitted to expand and enhance various insurance-related services, including financial planning and health care and nursing care services, by liberalizing the limitations on the scope of activity to be pursued by affiliates.

(3) With regard to the financial services, it is appropriate to permit the mutual entry of insurers, banks, trust banks and securities companies into other sectors of financial services. As to the method of mutual entry, it is appropriate, in principle, to adopt the sector-by-sector subsidiary approach based on the direction indicated by the financial system reform. As to the scope of activity of a subsidiary, such a subsidiary should be allowed to engage in every activity legally permitted in each financial sector. In the initial stage of mutual entry, however, certain limitations should be placed on the scope of activities of such a subsidiary from a viewpoint of ensuring equal and fair competition among various players, since the scope of activities by subsidiaries of other financial institutions is subject to similar limitations based on the proposed financial system reform. The scope of activity should be gradually expanded later on. When a subsidiary of an insurer enters either banking, trust banking or the securities business, it is appropriate for supervisory authorities to evaluate, through the approval process, the qualifications of the parent company from the viewpoint of soundness. On the other hand, when a subsidiary of a bank or other depository institution, a trust bank, or a securities company enters the insurance business, supervisory authorities should ensure that its parent concern has sufficient financial resources, such as capital and surplus, for entering the insurance business.

An insurer will be permitted to enter other sectors of financial services by incorporating a sector-by-sector subsidiary after the Insurance Business Law is amended. Major life insurers are now studying the possibility and feasibility of entering other sectors of financial services. Trust business and the securities business are the initial targeted business areas. Even if an insurer enters the securities business through a subsidiary, an insurer will be initially permitted to do the securities business only in the primary market, especially, the private placement market, and not be permitted to do stock brokerage business. As for the banking business, it is generally believed that there is little possibility of insurers' entry into the banking business due to the difficulty in establishing the infrastructure for the banking business and attaining a certain level of profitability.

(c) The financial system reform and actions of other financial institutions

As far as the financial system reform in Japan is concerned, a Bill on the Arrangement of Related Law for the Reform of the Financial System and Securities Business System was passed in June 1992. As a result, the mutual entry into other sectors of financial services through a banking subsidiary, a trust banking subsidiary and a securities subsidiary will be accomplished in April 1993. Based on the information available as of this writing, the following features can be pointed out.

(1) Ordinary banks, long-term credit banks, specialized foreign exchange banks and cooperative type of financial institutions including the Norinchukin Bank will be permitted to incorporate either a trust banking subsidiary or securities subsidiary, while trust 
banks and securities companies will be allowed to incorporate a securities subsidiary and a trust banking subsidiary, respectively. Ordinary banks, however, will be permitted to enter other sectors of financial services in 1994.

(2) A parent concern is required to own 100 percent of the voting stocks of its subsidiary, while the joint ownership of a subsidiary is not permitted.

(3) The scope of activities of a securities subsidiary of a bank is currently being discussed, and it has been determined that such a subsidiary is prohibited from transacting stock brokerage business for the time being. At the initial stage of mutual entry, a securities subsidiary of a bank will not be permitted to transact both underwriting of stock in the primary market and the stock dealing and brokerage business in the secondary market, while it will be permitted to transact the underwriting of convertible bonds and bonds with warrants but not the dealing and brokerage business for such securities. While a trust banking subsidiary will be legally authorized to engage in every activity permitted to a trust bank, at the initial stage, it will be permitted to engage in the fund trust business and securities investment trust business only among various types of money trusts.

(4) In order to ensure that the transactions between the parent concern and its subsidiaries are fair and equitable, various preventive measures against the harmful side effects and abuses, including the arms-length-rules based on the Securities and Exchange Law and the Banking Law, will be stipulated by both government and ministerial ordinances.

As the financial services industry in Japan is currently suffering from the aftermath of the so-called Bubble Economy, the operating environment for each sector of financial services is extremely harsh. Therefore, some concerns and apprehension have been voiced as to whether or not the time is ripe for proceeding with the financial system reform in such an environment. Nonetheless, as the necessary legislative measures have been taken in a steady manner, it is expected that the reform of the financial system will soon come into effect as scheduled. As it is anticipated that each financial institution will implement its own strategic course, a new era is about to arrive in the Japanese financial services industry.

\subsection{Diversification of distribution channels of insurance products}

(a) History of the exclusive life insurance agent system in the field of life insurance distribution

In Japan, life insurance policies are distributed through various channels including agents, agencies, over-the-counter at department stores, marketing arrangements with non-life insurers, banks, credit card companies, and direct mail orders via newspapers and magazines. According to a national survey conducted in 1991 by the Japan Institute of Life Insurance, in terms of number of policies, life insurance purchases through agents, accounting for $87.3 \%$ of total purchases, far outranked other channels, followed by agencies at $3.0 \%$, offices of life insurers at $2.1 \%$, over-the-counter at $0.3 \%$, and direct mail at $0.2 \%$.

The life insurance agent system has been a principal distribution channel and has been contributing to the development of the life insurance business in Japan. At the end of fiscal 1991, approximately 440,000 life insurance agents were registered. In order to become a registered life agent, a candidate has to take an industry-wide examination after 
being employed by a life insurer and completing company-sponsored training courses. After passing the examination, such a candidate is registered as a "life insurance solicitor" with the Ministry of Finance. Such life agents are assigned to a field organization of a life insurer such as regional offices and agency offices. Life insurers normally provide their life insurance agents with various opportunities for training and education and also control their daily work and sales activities. There are no mandatory requirements for life insurance agents to take various industry-sponsored examinations and continuing education programs after registration. These examinations and programs are voluntarily administered by both The Life Insurance Association of Japan and life insurers.

Although agencies are registered as life insurance solicitors like life insurance agents, they are commissioned or contracted by a life insurer and enter into an agency contract with a life insurer as an independent contractor and thus function as an independent sales organization. Accordingly, their relationship with a life insurer is different from the employer-employee relationship for a life insurance agent. While their share in total life insurance purchases is not so high, newly established life insurers accept this system as their principal distribution channel.

As far as the regulation of insurance distribution is concerned, distribution or solicitation of life insurance contracts is regulated by the Law Concerning the Control of Insurance Soliciting in Japan. Pursuant to the Law, (1) no person may engage in the soliciting of life insurance contracts unless registered as a life insurance solicitor under the Law, and (2) a life insurance solicitor means an officer or an employee of a life insurance company or an employee of those persons, or a person commissioned by a life insurance company, who acts as an intermediary in making life insurance contracts for the said company. Moreover, (1) a life insurance company is prohibited from appointing a life insurance solicitor of another life insurance company to engage in soliciting, and (2) a life insurance solicitor is prohibited from engaging in soliciting for another life insurance company by the Law. Therefore, the principle of one company representation is required and mandatory in the field of life insurance solicitation from standpoints of both a solicitor and a life insurer. On the other hand, in the field of non-life insurance solicitation, where the independent agency is a principal distribution channel, one company representation is not required and mandatory by the Law.

The origin of the principle of one company representation in the life business dates back to the Bill on the Control of Insurance Solicitation introduced in 1917. The Ministry of Agriculture and Commerce which had the regulatory authority over the insurance business in those days, tried to enact the proposed bill as there emerged many poorly managed or financially impaired insurers. Due to strong opposition by the industry, the proposed bill was not successfully enacted into a law. Afterwards, the Regulation of Insurance Solicitation was enacted in 1931 as the first statute relating to the soliciting of insurance contracts, which introduced the registration system of an insurance solicitor. Although this statute permitted the non-exclusive system, each insurer voluntarily avoided the multiple registration of an insurance solicitor in carrying out the registration process. In parallel with this movement, existing life insurance solicitors, who were allowed to be appointed by more than one life insurer in those days, had chosen to become exclusive agents representing a specific life insurer. The current Law Concerning the Control of Insurance Soliciting, which became effective in 1948, adopted the one company represen- 
tation system in the field of life insurance sales, considering that such realities existed and also that the one company representation system is better and more appropriate than the multiple representation or non-exclusive system from the viewpoints of securing the sound development of the industry and protecting the interests of policyholders.

(b) Recommendations by the Insurance Council Report regarding insurance distribution and their implications

Considering such factors as: (1) the necessity of introducing more diversified and efficient distribution channels based on specific features of insurance products, (2) proposed permission of the composite operation with non-life insurance business where the independent agency system on a non-exclusive basis is common and widely accepted, (3) tightening of the labor market due to the decrease in the number of younger workers resulting from the aging of the population, the Insurance Council recommended in its report that an existing regulation which mandates a life insurance solicitor to represent one specific life insurer be reviewed and amended, and indicated a future direction that the solicitation of business on a non-exclusive basis should be introduced even in the field of life insurance sales. This recommendation is not aiming to completely abolish a current requirement of one company representation in life insurance sales, but rather aiming to introduce initially the non-exclusive channel to certain product lines and channels where harmful side effects and abuses are least expected and then expand such a channel to other product lines and channels in a gradual manner. However, some people believe that the non-exclusive distribution channel might not be widely accepted in the field of life insurance sales, since the exclusive channel appears to be better and more desirable in that life insurance agents would be provided with more opportunities for training and education and be able to continue to offer quality post-sales services to policyholders under the exclusive system.

A brokerage system does not exist in the Japanese insurance distribution system at present, while it is an important distribution channel in some foreign countries. Considering also that criticism has been voiced that the non-existence of the brokerage system in Japan has been an obstacle for foreign insurers in entering the Japanese insurance markets, the Insurance Council recommended in its report that it be important to introduce the brokerage system and enable brokers to operate in the field of insurance distribution in Japan. In introducing the brokerage system, however, the Council stated that it is appropriate to study the introduction of certain requirements, including financial capacities of brokers to compensate for damages to a customer caused by them, the disclosure of commissions and the prohibition on acting as a general agency, for the purposes of protecting the interests of policyholders and consumers and assuring the neutrality and qualifications of brokers.

In addition, the Insurance Council reviewed insurance distribution by banks and other depository institutions. In Japan, insurance distribution by banks has not been permitted, pursuant to the statutory prohibition of non-banking business activity by banking institutions. In the review and discussion process at the Insurance Council, various opinions have been expressed with regard to insurance distribution by banks. Recognizing the disadvantages of bank distribution of insurance, some negative opinions were expressed, including (1) it is not expected that quality post-sales services would be properly provided in case of bank distribution of insurance, and (2) banks might take advantage of their substantial influence over customers in their insurance sales and might abuse existing information on individual customers. On the other hand, certain opinions favoring bank distribution of 
insurance have been expressed, including (1) it would enhance consumer benefits and convenience as a result of the insurance sales through extensive branch networks of banks, (2) it would contribute to the introduction of diversified and efficient distribution channels, (3) there exist certain product lines where the harmful side effects and abuses of insurance distribution by banks are less expected, and (4) after necessary measures against anticipated harmful side effects and abuses are in place, banks could be allowed to distribute insurance products. Therefore, the Insurance Council concluded that this issue should be reviewed in more detail in the context of financial system reform and from a standpoint of enhancing the consumer's convenience.

\subsection{Introduction of new regulations governing financial soundness of insurers}

While the Insurance Council indicated in its report that deregulation and liberalization be further promoted, it also recommended that the soundness of the insurance business be secured and further enhanced, as a prerequisite for the introduction of such deregulatory measures. In this section, I will describe the background and the contents of newly proposed regulations governing the financial soundness of insurers.

(a) The present insurance accounting system in Japan and its problem areas

Since it is imperative to have sound accounting principles for life insurers, very detailed accounting rules applicable to life insurers are set out in the Insurance Business Law, its Enforcement Regulation and the regulatory notices directed by the Banking Bureau of the Ministry of Finance. However, it is becoming necessary to review and update such existing accounting rules, in line with ongoing changes in the economic and social environments surrounding the insurance business. Several major problem areas in the current insurance accounting system in Japan are pointed out as follows.

\section{(1) Policy reserves}

The Enforcement Regulation of Insurance Business Law requires that policy reserves for life insurance policies consist of premium reserve, unearned premium, and contingency reserve, and that premium reserve be in principle valued according to a net level premium method but may be valued according to other methods including a fiveyear Zillmer method as an exception subject to approval of the Minister of Finance. Moreover, pursuant to a regulatory notice entitled "Improvement in the Level of Policy Reserves" directed by the Banking Bureau of the Ministry of Finance in 1968, life insurers were urged to hold their policy reserves on a net level premium method and at present most of life insurers are holding them based on said method. However, as the interest rates used for the valuation purposes are fixed at the same level as assumed interest rates for pricing purposes, and the dynamic valuation approach in which interest rates can be changed to reflect current economic environments is not introduced, it is sometimes suggested that the level of policy reserves is not adequate and sufficient.

(2) Treatment of realized capital gains and unrealized capital gains

Since private insurers in Japan are required to value their assets either at "cost" or at "lower of cost or market value" pursuant to the Commercial Code, insurers might accumulate unrealized capital gains on stocks, bonds, and real estate, equal to differences between book values and market values, and realized capital gains or losses are recognized when such assets are sold or reevaluated. 
Pursuant to the Article 86 of the Insurance Business Law, insurers in Japan are required to set aside the entire amount of net realized capital gains as a reserve in the liability section, which is called the Reserve under Article 86 of the Insurance Business Law. Pursuant to a proviso of said article, however, insurers are waived from setting aside all or a part of such capital gains as a reserve, subject to approval of the Finance Minister. Upon obtaining such approval, life insurers are allowed to distribute all or a part of such capital gains as well as current income from investments as special policyholder dividends to long-term policies which have been in force for a certain number of years. In addition, a regulatory notice was issued in 1983 to set out clear and detailed rules regarding the distribution of such realized capital gains as a part of special policyholder dividends. On the other hand, as far as ordinary policyholder dividends are concerned, life insurers in Japan are required to distribute ordinary policyholder dividends only out of current income from investments such as interest income on loans and bonds and dividends on stocks, and not out of realized capital gains. In Japan, such a rule regarding the ordinary dividend distribution is commonly called the "Income-Gain-Dividend-Principle".

This rule has played an important role in preventing the excessive and unsound competition among life insurers which might occur by allowing life insurers to pay ordinary dividends out of capital gains, and in securing and strengthening solvency margins of life insurers by accumulating unallocated surplus or internal reserves. In recent years, however, due to the introduction of sophisticated and advanced investment techniques as a result of the financial liberalization, it has become more difficult to make a clear distinction between capital gains and current income. It is also pointed out that, since the so-called Income-Gain-Divided-Principle has made life insurers more oriented toward current income than total return including capital gains, their investment approach has been to some extent distorted and biased, resulting in inefficient investment operations, deteriorating performance on a total return basis including capital gains, and increasing level of investments risks.

As for unrealized capital gains, pursuant to Article 84 of the Insurance Business Law, insurers are permitted, subject to approval of the Finance Minister, to recognize such gains to be distributed as a part of policyholder dividends or to be set aside as policy reserves. To date, no unrealized capital gains have been recognized, except for the variable life insurance field where separate accounts are utilized. It is sometimes pointed out that Article 84 and Article 86 are not consistent with each other. While it might be true that life insurers in Japan have conducted their risk management functions in the past by relying on such unrealized capital gains to a great extent, they are required to establish more appropriate risk management systems and to clarify the functions of unrealized capital gains on stocks, in a time when the amount of such unrealized capital gains on stocks is decreasing rapidly due to the plummet of Japanese stock markets.

(3) Segment accounting

In life insurance accounting in Japan, certain business results, including life insurance in force, policy reserves and premium income are accounted for and reported by major lines of business such as (i) individual life, (ii) individual annuity, (iii) group life, (iv) group annuity, (v) Workers' Asset Accumulation Insurance, (vi) Workers' Asset Accumulation Annuity, (vii) medical care, and (viii) reinsurance assumed. However, as there exists no uniform formula for allocating such items as operating expenses and investment income to each line of business, the operating result of each 
line of business is not available currently in Japan. While referring to a guideline issued by the Ministry of Finance, each life insurer is allocating such items, based on its own standards which it deems reasonable, to each of the following major lines of business, namely, (i) individual life and individual annuity, (ii) group life, (iii) group annuity, (iv) Workers' Asset Accumulation Insurance and Annuity, and (v) miscellaneous. It is sometimes pointed out that the allocation methods used by life insurers are not clear and not consistent with the methods followed by other financial industries.

(b) Recommendations by the Insurance Council Report regarding financial soundness of insurers

The Subcommittee on the Insurance Accounting, established under the Coordinating Committee of the Insurance Council, has discussed the insurance accounting system from such standpoints as (1) securing fairness and equity among policyholders, (2) promoting efficiency, (3) securing soundness, (4) promoting the principle of selfresponsibility, and (5) assuring clarity, while keeping in mind the aforementioned problem areas and also the changing economic and social environments. The Subcommittee issued a report entitled "The Review of Insurance Accounting and the Improvement in Disclosure". Based on this report, the Insurance Council recommended that an overall reexamination of current insurance accounting rules be conducted, including the introduction of solvency margin standards.

(1) Risk management system

As far as the risk management system of insurers in Japan is concerned, they have relied on, to a great extent, unrealized capital gains on stocks as an off-balance-sheet item. Considering that the amount of such unrealized capital gain can fluctuate and thus it is very uncertain in nature and also that such gains can be paid out as a source of policyholder dividends, it is not appropriate for them to be relying on those unrealized gains. Thus, while referring to risk management techniques in foreign countries, the Insurance Council recommended that the concept of solvency margins, defined as additional financial provision in excess of statutory policy reserves, be introduced in Japan and be used as a regulatory benchmark in monitoring and regulating financial soundness of insurers. In determining how both risk components and solvency margin components are accessed and calculated, the BIS's Risk-Adjusted Ratio for banks, the Capital Adequacy Requirement for security companies, the Risk Based Capital Requirements for the US life insurer, the Minimum Continuing Capital and Surplus Requirement for Canadian life insurers, and the Solvency Margin Standards in the EC countries should be referred to. Solvency margins could contain the contingency reserve, the Article 86 reserve, the unallocated dividend reserve, and a portion of unrealized capital gains on stock, in addition to total legal reserves and surplus in the case of mutual insurers or capital and surplus in the case of joint-stock insurers.

(2) Policy reserve valuation methods

As for the valuation method of policy reserves, while they are in principle valued by the net level premium method, a standard valuation method should be introduced, which would allow sufficient flexibility in terms of both the valuation method and assumptions used. It is also necessary to study the concept of Valuation Actuary, by which the chief actuary can conduct a reserve valuation process based on his or her own judgment, subject to given standards and rules. 
(3) Review of current rules and principles for distribution of dividends

It is necessary to review the existing rules and principles for distribution of dividends and to construct a fair and proper formula for distributing dividends based on total investment income including capital gains to policyholders. As a basic rule or principle for the dividend distribution, it is appropriate to study and introduce the assetshare method, which is to determine for each class of policyholder or policy its contribution to assets over the policy years from the standpoint of fairness among policyholders, and to ensure that a balance with financial products of other financial sectors is achieved. It is appropriate that the current prior approval system of policyholder dividend scales by regulatory authorities be in principle abolished provided that regulatory authorities issue guidelines regarding the dividend distribution rules through a regulatory notice and the chief actuary verifies and justifies the reasonableness of dividend scales. As for the current Article 86 Reserve, it is appropriate to clarify its nature and set out rules and standards regarding the categories of assets to be included in its calculation, the maximum reserve amount, the formula for additions and subtractions, and the treatment of the reserve as a liability or an unassigned surplus, by referring to the Asset Valuation Reserve which was introduced in the United States.

(4) Treatment of unrealized capital gains

Although the nature of unrealized capital gains on stocks has been rather unclear thus far, it is necessary to clarify their functions based on three categories, namely, (a) a portion to protect against future fluctuations in the market value of stocks, (b) a source of special dividends to be distributed to policyholders, and (c) protection against undue changes in the overall financial positions of an insurer. In applying such three categories of functions, the measurement of risks associated with the fluctuation of stock prices, contribution by each policyholder based on the asset share method, and the solvency margin level should be taken into consideration.

(5) Introduction and practical use of segment accounting and separate accounts It is appropriate that, at the initial stage, standards for allocating operating expenses and investment income and a segment accounting model be based on the four major lines of business, consisting of (i) individual life, (ii) group life, (iii) group annuity, and (iv) miscellaneous, and that such standards and a model be improved and expanded gradually in later stages.

In addition to these recommendations, the Insurance Council has made recommendations with regard to improvements in disclosure. A more detailed study of such recommendations is being conducted by the Follow-Up Study Group on the Insurance Accounting, which was established under the Director of the Insurance Department, Banking Bureau of the Ministry of Finance in June 1991.

\section{The Japanese life insurance market and its internationalization}

In relation to the Japanese life insurance market and its internationalization, I would like to briefly review the present conditions of foreign-based life insurers operating in Japan and the recommendations regarding the internationalization issue by the Insurance Council Report. 


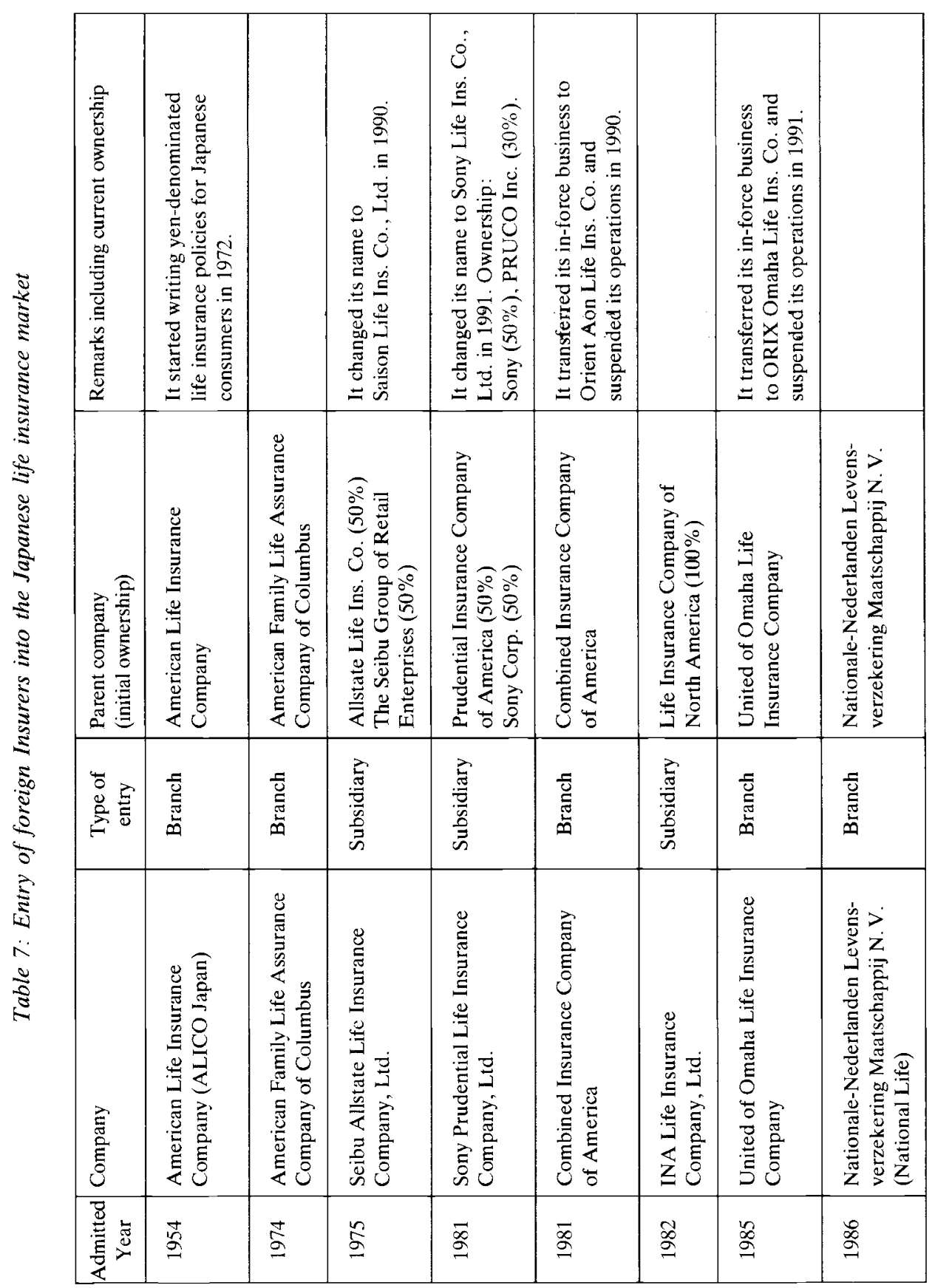




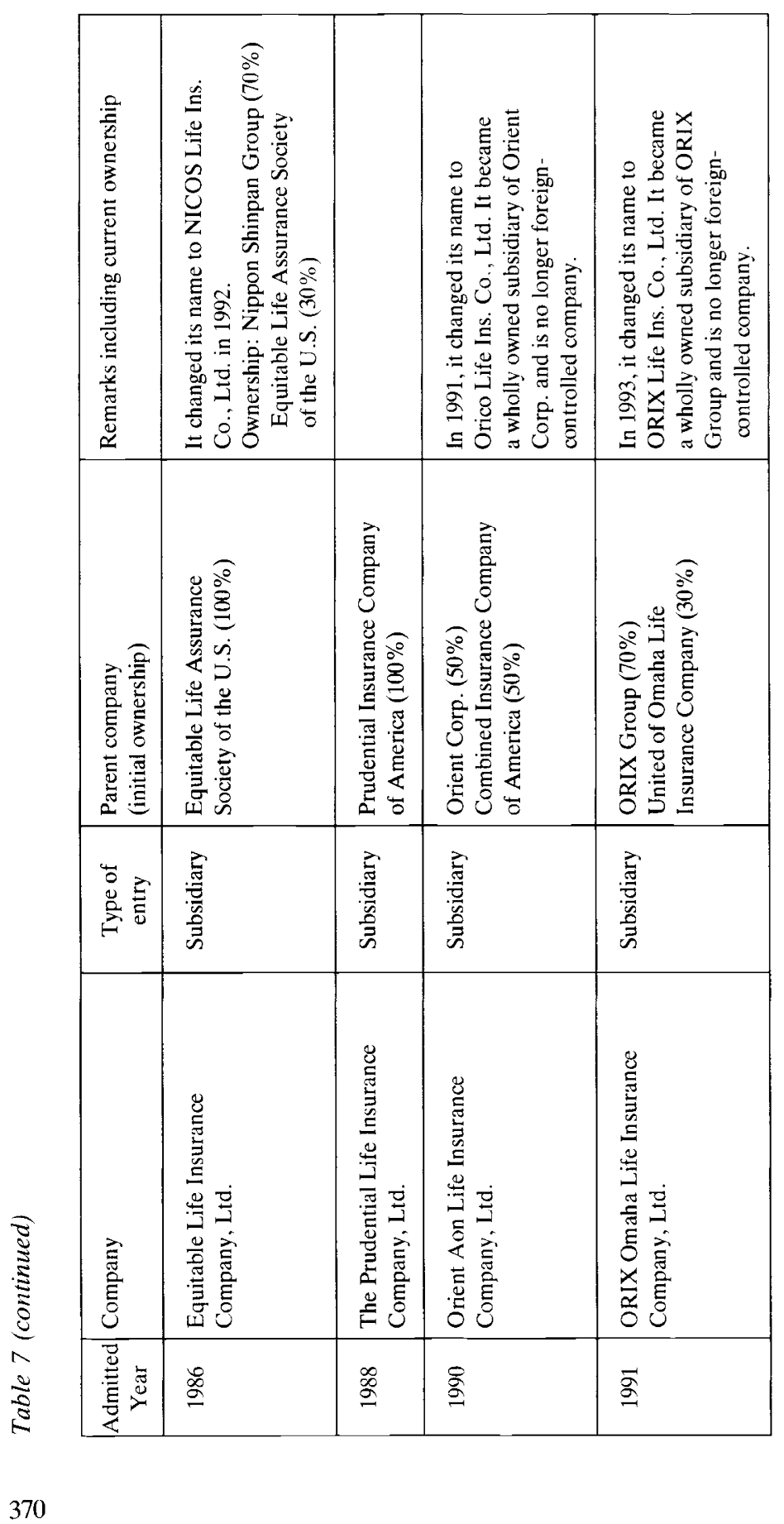


Foreign-based insurers can do insurance business in the Japanese markets through either branch offices or local insurance subsidiaries. As Table 7 shows, at present, three foreign-based insurers are authorized to do life insurance business through their branch office and five foreign-based insurers are admitted through local life insurance subsidiary, including two wholly-owned subsidiaries. In fiscal year 1991, approximately $¥ 700$ billion (US $\$ 5.9$ billion) of life insurance premiums were written in total by those eight foreignbased insurers and their total assets amounted to approximately $¥ 2$ trillion (US $\$ 18.6$ billion). Since aggregate premiums written and total assets of all private life insurers in Japan in fiscal 1991 were $¥ 28$ trillion and $¥ 143$ trillion, respectively, those foreign-based insurers accounted for approximately 2 to $3 \%$ of the Japanese life insurance market in terms of these measures.

While local insurance subsidiaries of foreign-based insurers operating in Japan, like other domestic insurers, are regulated and governed by the Insurance Business Law, branch operations of foreign-based insurers are regulated and governed as a "Foreign Insurer" by the Law Concerning Foreign Insurers which was enacted in 1949. As a result of the introduction of the Law, foreign-based insurers who had been selling insurance policies mainly to military members stationed in the bases in Japan and their families were required to obtain license from the Minister of Finance. Even after obtaining licenses, such foreign-based insurers continued to sell only dollar-denominated policies to such military personnel stationed in Japan. Thus, their impact on domestic insurers was negligible.

Afterwards, because of the rapid revival of the Japanese economy and resulting development of domestic insurers and the progress of internationalization, the regulatory authorities in Japan finally decided to admit foreign-based insurers into the Japanese life insurance market. Namely, in 1972, American Life Insurance Co. (ALICO) was authorized to sell yen-denominated life insurance policies to Japanese consumers as the first foreign-based insurer in the postwar period and entered the Japanese market through its branch office. Moreover, in 1975, Seibu-Allstate Life Insurance Company, Ltd., which was renamed to Saison Life in 1990, was established as a life insurance subsidiary jointly owned by The Seibu Group of Retail Enterprises in Japan (currently called as Saison Group) and Allstate Life of Sears-Roebuck Group in the United States, with 50\% interest held by each party. This subsidiary represented the first case in the postwar period, in which a domestic life insurer controlled by a foreign-based insurer obtained its license based on the Insurance Business Law. In granting a license, the Ministry of Finance had a guideline in those days, under which such foreign-controlled life insurers planning to enter the Japanese market were urged to introduce a type of product or distribution channel which was new to the Japanese life insurance market, in addition to requiring their financial soundness in their domiciled countries. In meeting such a guideline, ALI$\mathrm{CO}$, American Family, and Seibu Allstate introduced non-participating term life insurance, cancer insurance, and over-the-counter sales at department stores, respectively, and commenced their business in the Japanese life insurance market.

In parallel with the amendment to the Banking Law in 1981, by which statutory requirements for approval of foreign banks' operations in Japan were clarified and eased, this regulatory guideline applied to foreign-based insurers to introduce an unique type of product or distribution channel to the Japanese market was also abolished. However, as the entry of Equitable Life Assurance Society of the United States into the Japanese market 
promoted the introduction of variable life insurance in Japan, foreign-based insurers have affected the Japanese life insurance industry in its various aspects and contributed greatly to its development and growth. In 1988 when The Prudential Insurance Company of America commenced its business in Japan through its wholly-owned subsidiary, ten foreign-based insurers were doing life insurance business in Japan, with five such insurers operating through local life insurance subsidiaries and the remaining five through branch operations. In recent years, three foreign-based insurers withdrew from the Japanese life insurance market by transferring all or a part of their stake in a life insurance subsidiary to Japanese non-bank banks.

The Subcommittee on International Affairs, which was organized under the Coordinating Committee of the Insurance Council, reviewed and discussed the internationalization issue from the standpoints of both protecting interests of policyholders and promoting a fair and open competition in the international insurance trade. The Insurance Council acknowledged that it is rather natural and unavoidable that the regulation of foreign-based insurers is different from that of domestic insurers in some respects, due to the fact that these foreign insurers are domiciled in foreign countries over which the regulatory authorities in Japan have no jurisdiction and controls. The Insurance Council recommended, however, that foreign insurers be in principle treated and regulated in an equal manner as domestic insurers and that certain legislative measures be taken, including the consolidation of the Law Concerning Foreign Insurers with the Insurance Business Law, when the Insurance Business Law and related statutes are amended in the future.

\section{Outlook for the Japanese life insurance business}

As I have stated in the beginning, although the trend toward market saturation, especially in the death protection market, is progressing in the life insurance markets in Japan, it is expected that there will be additional needs for life insurance protection in line with the steady economic growth. While the death protection market continues to be a primary market for the Japanese life insurers, it is thought that consumer needs for annuity contracts and health and nursing care insurance policies will continue to grow, considering such factors as the review and amendment of the social security system, which will probably result in additional financial responsibilities on the part of each consumer, the growing expectations for and concern with income security after retirement, and the increase in the number of nuclear families. As a result, it is anticipated that both the annuity and the health insurance businesses will account for a higher proportion of the life insurance business. It is important to note here that such a shift, which has already begun in the individual and family markets, has occurred in the employee benefit plan, including pension plan, markets.

In relation to the Studies on the Four Pillars which constitute one of the major study areas of the Geneva Association, as the life insurance industry has been and will continue to be involved directly with the second pillar of occupational pension schemes and the third pillar of individual savings, it is considered that the roles and importance of the life insurance industry will be further expanded and enhanced in a time when the aging of population is rapidly advancing in Japan. Therefore, as far as the overall market environment is concerned, although the death protection market is projected to be gradually approaching maturity, the life insurance business in Japan as a whole, which once achieved 
a rapid and remarkable growth, will grow and expand at a steady and stable pace due to the projected increase in the need and demand for the annuity and health insurance products.

In this paper, I have reviewed the recent trends in the Japanese life insurance industry, in particular, the changing regulatory trends and environments, focusing on the Insurance Council Report issued in June 1992. As for the future direction of the insurance system rcform based on the Insurance Council Report, the Legislative Committee which was established in July 1992 began conducting a detailed study and research with regard to the revision of the insurance-rclated statutes, including the Insurance Business Law. A proposed bill will be submitted to the Diet after the Legislative Committee completes its review and discussion process. It is projected at the present moment that the bill will probably be submitted to the 1994 spring session of the Diet at earliest and the law will become effective one year after it is passed.

Considering both the reform of the insurance system soon to be implemented and the cver intensifying competition in the market, it is anticipated that each life insurer in Japan will be facing an even tougher and more competitive operating environment despite the projected steady growth of the industry as a whole. While only 30 life insurers are currently operating in the Japanese life insurance markets, the number of admitted life insurers is expected to increase in the near future due to the increase in the number of new entrants into the life insurance markets. It is quite likely that non-life insurers in Japan will enter the life insurance markets through a subsidiary as the existing limitation on the composite operation of life and non-life businesses will be liberalized. Also, other financial institutions might enter the life market through a life insurance subsidiary. In particular, competition in the annuity markets, which are projected to grow rapidly in line with the advent of the aging society, will be further intensified.

It is also projected that the product profitability will deteriorate to some extent in the future as the liberalization of both premium rates and policyholder dividend scales is expected to be further promoted. In order to remain competitive under such conditions, each life insurer will be required to continue to make efforts in strengthening its investment operations and enhancing its operational efficiency. Provided that existing major life insurers continue to make such efforts in an effective way, they will be able to maintain their dominant market position in the foreseenable future despite the further intensified competitive pressures including the increasing number of new entrants, by capitalizing on both their management resources and extensive customer base, which they have developed in the course of their long years of operations.

On the other hand, there will be various opportunities for diversification and entry into the new markets, from which life insurers had been prohibited, but will be permitted to enter through subsidiaries pursuant to the proposed direction of reform of both insurance system and financial system. Such opportunities include the introduction of the all-lines approach by entering the non-life insurance markets through a subsidiary and the diversification into other sectors of financial services through a subsidiary to provide a wide range of financial products from one source. As far as such a diversification strategy is concerned, it is true that such an approach has ccrtain advantages in that it will cater to the consumer's convenience and benefit and that certain synergies will be expected as a group. Moreover, such an approach might become necessary from a competitive standpoint, as other financial institutions might employ such a diversification approach. 
It is, however, very important to keep in mind that, in pursuing such a diversification strategy, a substantial amount of capital outlay is needed and sizeable risks are involved. Also, such new ventures might suffer from poor profitability. Taking into account an essential mission for a life insurer, in particular, for a mutual life insurer, of providing life insurance benefits at the lowest cost possible, and quality services to policyholders to maximize their satisfaction, each life insurer should determine after careful and deliberate review and analysis whether such a rapid and broad diversification style can be justified from a standpoint of accomplishing such a mission and also from the standpoints of ensuring financial soundness and proper risk management, including satisfying the solvency margin standards to be implemented.

In relation to the internationalization trend, while I believe that the Japanese life insurance markets have not been closed to new entrants from abroad, it is necessary that insurance regulation and taxation in Japan be made further consistent and harmonized with the basic principles on trade in services in the Uruguay Round negotiations under the General Agreement on Tariffs and Trade. In revising and amending the insurance-related statutes in Japan, the following five key fair-trade principles should be taken into consideration, based on the discussions regarding the fair-trade disciplines at the Uruguay Round: (1) market access, (2) national treatment, (3) most-favored-nation treatment, (4) transparency, and (5) reciprocity. I hope that the cooperation and understanding among trading partners will be further promoted.

The proposed reform of the insurance system, together with the financial system reform, will bring about drastic changes in the existing framework of regulation and supervision of the financial services industry, including the insurance industry, which has lasted during the past several decades. Considering the history and tradition of regulation and supervision of financial institutions and insurers in Japan, it is rather unlikely that the reform will be implemented in a rapid and hurried manner. While it is expected that the deregulation measures will be introduced and implemented in a gradual and orderly manner in Japan, the trends towards both liberalization and internationalization will be more pervasive and visible in the Japanese financial services industry, including the life insurance industry, in the twenty-first century. A new era, in which each life insurer in Japan will be forced to make a critical decision in charting its own future strategic course, is about to be ushered in. It is the author's belief, however, that major life insurers in Japan will continue to grow and prosper by further developing their core life insurance and annuity businesses, even under such changing business environments.

(The article was written in March 1993 and reflects the facts and data available as of March 1993.) 